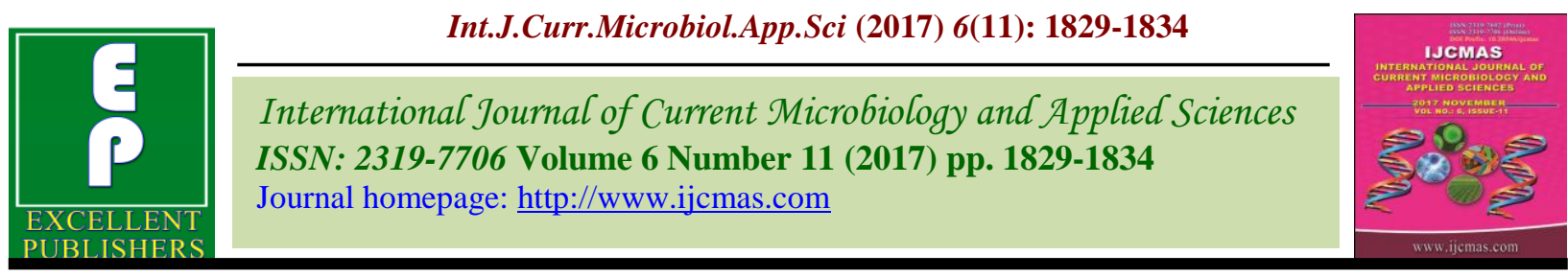

Original Research Article

https://doi.org/10.20546/ijcmas.2017.611.218

\title{
In-Vitro Regeneration of Aloe Vera (Aloe barbadensis Mill)
}

\author{
Shashi Kiran ${ }^{1}$, Alice Tirkey ${ }^{*}{ }^{*}$ Zenu Jha ${ }^{2}$ and S.S. Porte ${ }^{3}$ \\ ${ }^{1}$ Department of Genetics and Plant Breeding, Indira Gandhi Krishi Vishwavidyalaya, \\ College of Agriculture, Raipur- 492012, Chhattisgarh, India \\ ${ }^{2}$ Department of Plant Molecular Biology and Biotechnology, Indira Gandhi Krishi \\ Vishwavidyalaya, College of Agriculture, Raipur- 492012, Chhattisgarh, India \\ ${ }^{3}$ Department of Soil Science, Indira Gandhi Krishi Vishwavidyalaya, College of Agriculture, \\ Raipur- 492012, Chhattisgarh, India \\ *Corresponding author
}

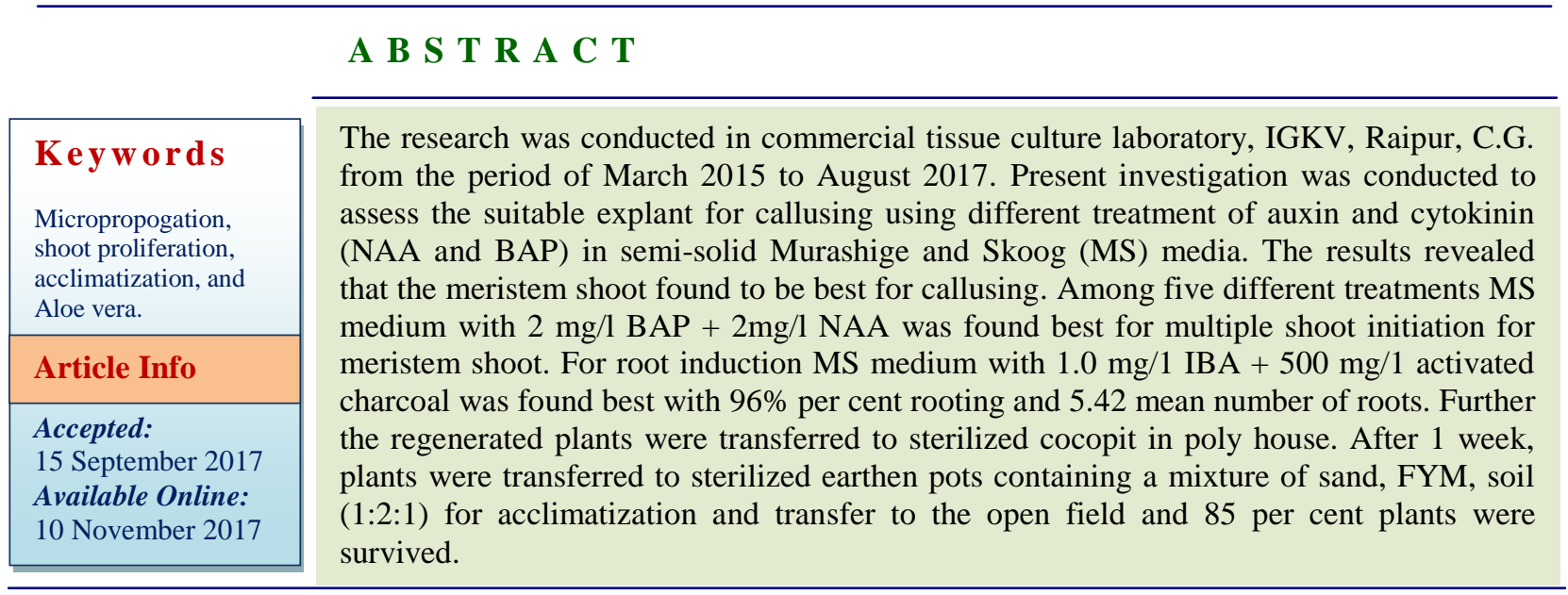

\section{Introduction}

Aloe vera (Indian Aloe) is an important medicinal and miracle plant that belongs to the family Liliaceae. The gel in the leaves provide an excellent treatment for wounds, burns and other skin disorders, placing a protective coat over the affected area, speeding up the rate of healing and reducing the risk of infection. Aloe vera contains different bioactive materials such as saponins, anthraquinones, mucopolysaccharides, steroids, vitamins and glucomannans (Liu et $a l ., 2006,2007)$. Due to the wide spectrum of application in human health, the products of A. vera have showed a strong demand in India as well as in international markets. In nature, A. vera is propagated through lateral buds, which is slow, expensive and low income practice (Aggarwal and Barna, 2004). There is a lack of production of Aloe leaf to meet the industry demand and so it is necessary to undertake large scale cultivation of Aloe. The flowers are hermaphrodite; plant prefers light (sunny weather), requires well-drained soil and can grow in nutritionally poor soil (Dwivedi et al., 2014). Pharmaceutical and cosmetic industry has great demand in $A$. vera. Global Demand for Aloe vera extracts to Reach 60720 Tonnes in 2016 (Future 
market in sight, 2016). Due to slow rate of natural growth, ever increasing demand for this "Potted Physician" cannot meet with traditional method of propagation, hence there is need for mass propagation of this plant through in vitro method to fulfil the demand of pharmaceutical and cosmetic industries (Kumari and Naseem, 2015). It is in great demand for its medicinal and cosmetic properties by rural, urban and tribal folks (Kliein and Penneys 1988), the cultivation of this wonder drug plant is now a days encouraged by herbal experts and researchers.

The hormonal requirement for in vitro differentiation differs for different genotypes. The objective of this investigation was to assess the suitable explant for callus formation, different concentration and combination of phytohormones (Auxin and cytokinin) for shooting and rooting response, hardening and transfer of regenerated plants to the field for uniform harvesting of the aloe leaf.

\section{Materials and Methods}

\section{Plant material sources}

The three month old suckers of aloe vera were obtained from field collection of herbal garden of IGKV, Raipur (C.G).

\section{Sterilization of explant}

Contamination free culture is the first step in development of the regeneration protocol for any plant species. Initially all the excised plant tissue were washed thoroughly with $7 \%$ labolene and rinsed thoroughly with sterile double distilled water. All the explants were sterilized by using three different surface sterilization treatments (Table 1). For optimization of sterilization condition each treatment after final step in all explants i.e. apical shoot meristem, root tip, leaf tip and spine were excide from aloe vera plants in an air sterile chamber and inoculated in to shoot proliferation medium based on Murashige and Skoog medium. The MS media of Hi-media was prepared as stoke solution of $1 \mathrm{~L}$ by weighing $4.41 \mathrm{gm}$ of MS media of Hi-media by adding $30 \mathrm{~g}$ of sucrose followed by $0.50 \mathrm{~g}$ PVP. The $\mathrm{pH}$ was maintained between 5.75 and 5.80. The solution was heated and agar $8 \mathrm{~g}$ was added in it after that the solution was poured in bottles up to $1 \mathrm{~cm}$.

\section{Shoot proliferation}

Three explants were cultured on MS nutrient medium supplemented with five different concentration of BAP Table 1. The explants showing shoot proliferation on basis of number of total shoots per explants and length of the longest shoots were considered as parameters. The data was recorded for shoot proliferation in suitable medium and further sub culturing of proliferated shoots.

\section{Rooting of micro shoots}

Newly formed shoots measuring $2-3 \mathrm{~cm}$ in length were excised individually from the parent explant and transferred to rooting media after 7 sub culture. For rooting four types of growth regulators MS (half) +0.5 $\mathrm{mg} / \mathrm{l} \mathrm{IBA}+500 \mathrm{mg} / \mathrm{l}$ activated charcoal, MS (half) $+0.5 \mathrm{mg} / \mathrm{l} \mathrm{IBA}$, MS (half) $+0.5 \mathrm{mg} / \mathrm{l}$ IAA $+500 \mathrm{mg} / \mathrm{l}$ activated charcoal, Basal MS (half) medium $+500 \mathrm{mg} / \mathrm{l}$ activated charcoal were used in different concentration in addition to MS medium and observation was recorded for rooting response.

\section{Acclimatization}

Regenerated plantlets of 6-8 weeks old with well-developed roots were removed from culture vessels and washed thoroughly with the tap water to remove the Agar media. The roots were treated with $0.2 \%$ bavistin for 30 
to 45 seconds and transferred to sterilized cocopit in green house with automatically controlled relative humidity, proper misting and irrigation and air exhaustion. After one week, plants were transferred to sterilized earthen pots containing a mixture of sand, FYM, soil at a ratio of $1: 2: 1$. The potted plants were kept in the conventional net house for acclimatization before transfer to the open field. Plants were watered at two days interval.

\section{Results and Discussion}

Sterilization, explants response, shoot differentiation and rooting

Among the treatment given good response for surface sterilization of explants was seen in explants when dipped in $1.0 \%$ bavistin for 30 minutes followed by $0.1 \% \mathrm{HgCl}_{2}$ for 45 minutes followed by washing with double sterilized water followed by dipping in $2 \%$ $\mathrm{NaOCl}$ for $20 \mathrm{~min}$. then dipping in $70 \%$ ethanol for 30 second. This sterilization procedure gave contamination free explants. The four explants viz., apical shoot bud, meristem root tip, leaf tip and spine of $1.5 \mathrm{~cm}$ were subjected to the MS medium supplemented with different concentration of $\mathrm{BAP}+\mathrm{NAA}$ for their response.

Apical shoot bud, leaf tip, spine dose not showed any response, whereas, apical shoot showed multiplied. Further these responsive explants, were used for the standardization of protocol. The size of explants at time of culture was found critical for shoot initiation. Similarly, Gupta et al., (2014) studied various explants such as apical, nodal segments and leaves were tested for understanding in-vitro response in the nutrient media. Among the 3 explants, the apical bud explants gave the best results and were used for further experiments (Kumari et al., 2015). MS medium with 2 $\mathrm{mg} / \mathrm{l} \mathrm{BAP}+.2 \mathrm{mg} / \mathrm{l} \mathrm{NAA}$ was found best for multiple shoot initiation for apical shoot bud. As they produced 5.0 mean number of shoots/explant with $92.85 \%$ shoot initiation response. The similar results were obtained by Kumari et al., (2015), Ahmad et al., (2007), Gupta et al., (2014) and Mehta (2013). However, MS medium supplemented with 4 $\mathrm{mg} / \mathrm{l} \mathrm{BAP}+0.2 \mathrm{mg} / \mathrm{l} \mathrm{NAA}$ also produced good number of multiple shoot with 3.69 mean number of shoots/ explants.

Among other treatment except the treatments mentioned above using MS medium containing $0.2 \mathrm{mg} / 1 \mathrm{NAA}$ in the combination unit $3,5,8 \mathrm{mg} / \mathrm{l}$ BAP were found to be less responsive for meristem shoot explants with mean 2.6, 2.45 and 1.66 mean number of shoots/explant respectively under study.

For root induction, it was observed that basal MS medium devoid of phytohormones also induce rooting but percentage of rooting and number of roots per shoot were observed. IBA was found best for induction of roots followed by IAA. IBA supplemented at 1.0 $\mathrm{mg} / \mathrm{l}$ induced highest frequency of rooting. The best result was obtained by using MS medium with $1.0 \mathrm{mg} / 1$ IBA $+500 \mathrm{mg} / 1$ activated charcoal.

This produced good roots with $96 \%$ per cent rooting and 5.42 mean number of roots, whereas, 2.26 mean number of roots/shoot were obtained with $89.06 \%$ per cent rooting on half strength MS medium with $1.0 \mathrm{mg} / 1$ IAA $+500 \mathrm{mg} / 1$ activated charcoal. When apical shoot buds were culture using MS medium with $1.0 \mathrm{mg} / 1$ IBA $+500 \mathrm{mg} / 1$ activated charcoal development of root was observed on explant. This result coincides with the findings of Mehta (2013) and among the three types of auxins NAA was found to be the best for root induction. MS medium containing BA and NAA was found to be the best medium in Aloe micropropagation (Gupta et al., 2014) (Tables 2 and 3). 
Different stages of apical shoot bud

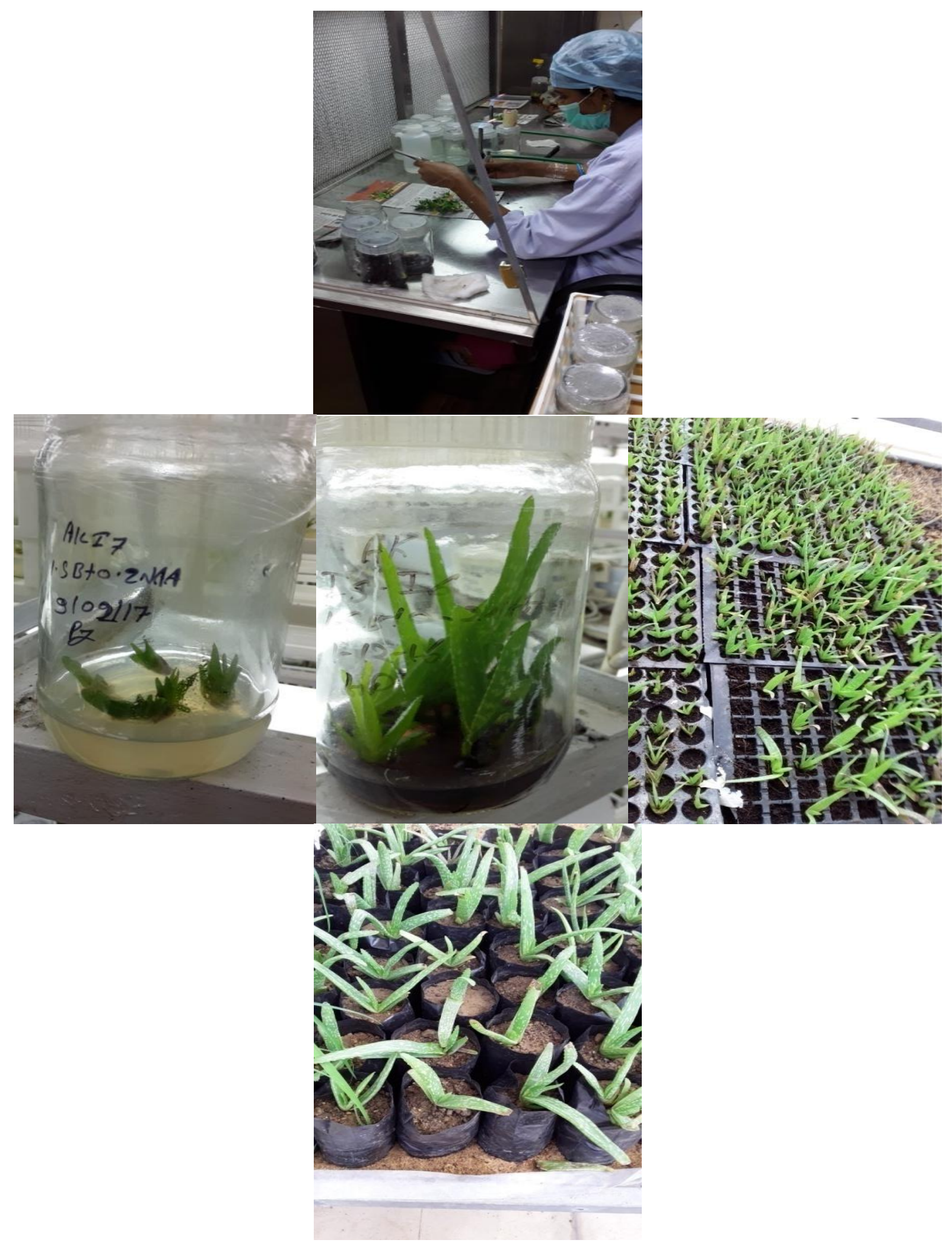


Table.1 Effect of different combination of hormones for shoot initiation

\begin{tabular}{|c|c|c|c|c|c|c|c|c|}
\hline $\begin{array}{l}\text { Treatment } \\
\text { code }\end{array}$ & Hormone combination & $\begin{array}{c}\text { Number of } \\
\text { explant } \\
\text { Inoculated }\end{array}$ & $\begin{array}{l}\text { No. of culture } \\
\text { contaminate }\end{array}$ & $\begin{array}{c}\text { No. of } \\
\text { explant } \\
\text { response } \\
\end{array}$ & $\begin{array}{l}\text { No. of explants } \\
\text { shoot initiated }\end{array}$ & $\begin{array}{c}\text { No. of shoot } \\
\text { initiated/plant } \\
\text { Range }\end{array}$ & Mean & \% Response \\
\hline $\mathrm{T}_{1}$ & $3 \mathrm{mg} / 1 \mathrm{BAP}+0.2 \mathrm{NAA}$ & 16 & 1 & 3 & 12 & $1-4$ & 2.6 & $80 \%$ \\
\hline $\mathrm{T}_{2}$ & $5 \mathrm{mg} / 1 \mathrm{BAP}+0.2 \mathrm{NAA}$ & 16 & 3 & 2 & 11 & $2-3$ & 2.45 & $84.6 \%$ \\
\hline $\mathrm{T}_{3}$ & $8 \mathrm{mg} / 1 \mathrm{BAP}+0.2 \mathrm{NAA}$ & 16 & 1 & 5 & 10 & $1-2$ & 1.66 & $66.66 \%$ \\
\hline $\mathrm{T}_{4}$ & $2 \mathrm{mg} / 1 \mathrm{BAP}+0.2 \mathrm{NAA}$ & 16 & 2 & 1 & 13 & $5-7$ & 5.0 & $92.85 \%$ \\
\hline $\mathrm{T}_{5}$ & $4 \mathrm{mg} / 1 \mathrm{BAP}+0.2 \mathrm{NAA}$ & 16 & 1 & 2 & 13 & $2-5$ & 3.69 & $86.66 \%$ \\
\hline
\end{tabular}

Table.2 Effect of different treatments on rooting response

\begin{tabular}{|c|c|c|c|c|c|c|}
\hline $\begin{array}{l}\text { Treatment } \\
\text { Rooting hormones }\end{array}$ & $\begin{array}{l}\text { No. of culture } \\
\text { inoculated }\end{array}$ & $\begin{array}{l}\text { No. of plant } \\
\text { contaminated }\end{array}$ & $\begin{array}{l}\text { No. of plant } \\
\text { responded }\end{array}$ & $\begin{array}{c}\text { No. of plant root } \\
\text { responded }\end{array}$ & Mean & $\begin{array}{c}\text { Plant Response } \\
\text { in } \% \\
\end{array}$ \\
\hline $\begin{array}{l}\text { MS }(\text { half })+0.5 \mathrm{mg} / \mathrm{IBA}+ \\
500 \mathrm{mg} / \mathrm{l} \text { activated charcoal }\end{array}$ & 64 & 1 & 1 & 62 & 5.42 & $96.87 \%$ \\
\hline MS (half) + 0.5 mg/l IBA & 64 & 10 & 12 & 40 & 1.71 & $74.07 \%$ \\
\hline $\begin{array}{l}\text { MS }(\text { half })+0.5 \mathrm{mg} / \mathrm{l} \text { IAA }+ \\
500 \mathrm{mg} / \mathrm{l} \text { activated charcoal }\end{array}$ & 64 & 2 & 9 & 53 & 2.26 & $84.12 \%$ \\
\hline Basal MS (half) medium (MSO) & 64 & 2 & 9 & 50 & 1.95 & $80.64 \%$ \\
\hline $\begin{array}{l}\text { Basal MS (half) medium }+\mathbf{5 0 0} \\
\text { mg/l activated charcoal }\end{array}$ & 64 & 1 & 9 & 54 & 2.15 & $84.37 \%$ \\
\hline
\end{tabular}

Table.3 Effect of different treatments on rooting response

\begin{tabular}{|c|c|c|c|}
\hline Media & Rooting percentage & $\begin{array}{l}\text { Mean no. of } \\
\text { roots/explant }\end{array}$ & Type of root response \\
\hline $\begin{array}{l}\text { Basal MS (half) medium }+500 \text { mg/l activated } \\
\text { charcoal }\end{array}$ & $92.18 \%$ & 2.15 & Long thick root, Tap root. \\
\hline $\begin{array}{l}\text { MS }(\text { half })+0.5 \mathrm{mg} / \mathrm{IBA}+500 \mathrm{mg} / \mathrm{l} \text { activated } \\
\text { charcoal }\end{array}$ & $96.87 \%$ & 5.42 & $\begin{array}{l}\text { Bunchy type, hairy type, fibrous } \\
\text { root. }\end{array}$ \\
\hline $\begin{array}{l}\text { MS }(\text { half })+0.5 \mathrm{mg} / \mathrm{I} \mathrm{IAA}+500 \mathrm{mg} / \mathrm{l} \text { activated } \\
\text { charcoal }\end{array}$ & $89.06 \%$ & 2.26 & Long few no. long thin type. \\
\hline MS (half) $+0.5 \mathrm{mg} / \mathrm{I}$ IBA & $87.5 \%$ & 1.71 & Bunchy type, thin root. \\
\hline
\end{tabular}


Acclimatization of plants and transfer of regenerates to field

Regenerated plantlets of 6-8 weeks old with welldeveloped roots were removed from culture vessels, washed thoroughly with the tap water to remove the Agar media.

The roots were treated with $0.2 \%$ bavistin for 30 to 45 seconds and transferred to sterilized cocopit in poly house. After 1 week, plants were transferred to sterilized earthen pots containing a mixture of sand, FYM, soil at a ratio of 1:2:1. The potted plants were kept in the net house for acclimatization before transfer to the open field. Plants were watered at two days interval. More than 85 per cent of the potted plants survived after one month of transfer and could be successfully transferred to the field. The same media as that of polybag were used by Ahmed et.al. (2007).

In the present investigation, using different concentrations and different explants, it has been concluded that aloe vera can be successfully regenerated using in-vitro techniques, if the proper concentrations of plant growth regulators and initial explant tissues is made. The high frequency plant regeneration system for in vitro production of aloe vera through meristem shoot tip explants has been developed during the present investigation. Various factors affecting the plant regeneration system has been examined and standardized and opens avenues for large-scale production of genetically stable planting materials. Commercial micropropagation of aloe vera could be successfully performed utilizing apical shoot bud as explants for uniform harvesting of the aloe vera.

\section{Acknowledgements}

The first author is thankful to all the staff members of Department of Genetics and Plant Breeding and Commercial Plant tissue culture Laboratory, IGKV, Raipur, CG. For their support and encouragement during the course of investigation.

\section{References}

Aggarwal, D. and Barna, K.S. 2004. Tissue culture propagation of elite plant of Aloe vera Linn. Journal of Plant Biochemistry and Biotechnology. 13: 77-79.

Ahmed, S., Kabir, A. H., Ahmed, M. B. and Razvy, M. A. 2007. S. Ahmed i sur.: Development of rapid micropropagation method of Aloe vera L. Seed Science Journal. 24(2): 121-128.

Dwivedi, N. K., Indiradevi, A., Asha, K. I., Nair, R. A. and Suma, A. 2014. A protocol for micropropagation of Aloe vera L. (Indian Aloe)- a miracle plant, Research in Biotechnology. 5(1): 1-5.

Global demand for aloe vera extracts to reach 60720 tonnes in 2016: Emergence of innovative, high quality and cost effective products ramping up adaptation. https://www.futuremarketinsights.com/repo rts/aloe-vera-extracts-market.

Gupta, S., Sahu, P. K., Sen, D. L. and Pandey, P. 2014. In-vitro Propagation of Aloe vera (L.) Burm. F. British Biotechnology Journal 4(7): 806-816.

Klein, A. D. and Penneys, N. S. 1988. Aloe vera. J. Am. Acad. Dermatol. 18: 714-720.

Kumari, A., Naseem, MD. 2015. An efficient protocol for micropropagation of a medicinal plant Aloe vera $\mathrm{L}$. Through organ culture. J. Indian bot. Soc. 94 (1\&2): 118125.

Liu, C. H., Wang, C. H., Xu, Z. L. and Wang, Y. 2007. Isolation, chemical characterization and antioxidant activities of two polysaccharides from the gel and the skin of Aloe barbadensis Miller irrigated with seawater Process. Biochem. 42: 961-970.

Mehta, S. 2013. In-vitro Multiplication of Aloe vera L. - An Important Medicinal Plant, Vegetos, 26(special): 155-159.

\section{How to cite this article:}

Shashi Kiran, Alice Tirkey, Zenu Jha and Porte, S.S. 2017. In-Vitro Regeneration of Aloe Vera (Aloe barbadensis Mill). Int.J.Curr.Microbiol.App.Sci. 6(11): 1829-1834.

doi: https://doi.org/10.20546/ijcmas.2017.611.218 